\title{
Uma concepção minimalista e garantista da presunção de inocência ${ }^{1}$
}

\author{
A Minimalist and Garantistic Conception \\ of the Presumption of Innocence
}

Jordi Ferrer Beltrán

Professor de Filosofia do Direito da Universitat de Girona - Espanha

Diretor da Cátedra de Cultura Jurídica

jordi.ferrerb@udg.edu

orcid.org/0000-0002-5684-6721

Resumo: $O$ artigo visa abordar as múltiplas facetas que a presunção de inocência incorpora nos modernos sistemas jurídicos desde uma perspectiva crítica. Neste sentido, a partir de uma metodologia analítica busca-se demonstrar que algumas dessas facetas se sobrepõem a outros direitos e institutos jurídicos o que, finalmente, longe de aumentar as garantias dos cidadãos, chega a produzir confusão e falta de controlabilidade das decisões judiciais. Assim, defende-se a conveniência conceitual e prática de se pensar a presunção de inocência evitando sobreposições com outros direitos ou conceitos jurídicos; como standards de prova ou ônus da prova. Daí a referência a uma concepção minimalista e garantista da presunção de inocência e, como será possível ver, a defesa da presunção de inocência como uma regra de segunda ordem cuja aplicação cobraria sentido em contextos de incerteza sobre a satisfação do standard de prova.

Palavras-chave: presunção de inocência; minimalismo conceitual; standards de prova; regra de segunda ordem; contexto de dúvida.

AвSTRACT: The article aims to address the multiple faces that the presumption of innocence incorporates in modern legal systems from a critical perspective.

1 Artigo publicado originalmente em espanhol em: MARTÍ MARMOL, Josep Lluís; MORESO, Josep Joan (orgs), Contribuciones a la filosofía del derecho, Madrid: Marcial Pons, 2012. Tradução ao português de Janaina Matida, Professora de Teoria do Direito da UFRJ, doutoranda da Universitat de Girona (Espanha). 
In this sense, an analytical methodology seeks to demonstrate that some of these faces overlap with other legal rights and institutes, which, far from increasing the guarantees of citizens, leads to confusion and lack of controllability of judicial decisions. Thus, it is defended the conceptual and practical convenience of thinking the presumption of innocence avoiding overlaps with other legal rights or concepts, as standards of proof or burden of proof rules. Hence the reference to a minimalist and guarantistic conception of the presumption of innocence and, and, as will be seen, the defense of the presumption of innocence as a second order rule whose application would make sense in contexts of uncertainty about the satisfaction of the standard of proof.

KEYWORDS: presumption of innocence; conceptual minimalist; standards of proof: second order rule; context of doubt.

SUMÁRIo: Introdução; 1. As distintas facetas da presunção de inocência; 1.1. A dimensão extraprocessual da presunção de inocência; 1.2. A dimensão processual da presunção de inocência; 1.2.1. A presunção de inocência como princípio informador do processo penal; 1.2.2. A presunção de inocência como regra de tratamento processual; 1.2.3. A presunção de inocência como regra probatória; 1.2.4. A presunção de inocência como regra de julgamento; 2 . De novo sobre a presunção de inocência como regra sobre o ônus da prova; Conclusão.

\section{INTRODUÇÃO}

Apesar do recente reconhecimento no direito espanhol do direito fundamental à presunção de inocência ou, quem sabe, precisamente por ele, muitos são os trabalhos que têm se dedicado à sua análise e já chegam a milhares as decisões nas quais o alcance desse direito e de sua proteção foram os objetos principais do debate.

Com efeito, a vigente Constituição de 1978 é o primeiro texto jurídico espanhol no qual se reconhece expressamente e com esse nome o direito à presunção de inocência no processo penal ${ }^{2}$. Isso não

2 O artigo 24.2 da vigente Constituição espanhola estabelece que: "Asimismo, todos tienen derecho al Juez ordinario predeterminado por la ley, a la 
supõe, evidentemente, que esse direito, ou alguma de suas facetas, foi totalmente desconhecido para o direito espanhol anterior a essa data. De fato, o próprio Tribunal Constitucional repetiu frequentemente em sua

defensa y a la asistencia de letrado, a ser informados de la acusación formulada contra ellos, a un proceso público sin dilaciones indebidas y con todas las garantías, a utilizar los medios de prueba pertinentes para su defensa, a no declarar contra sí mismos, a no confesarse culpables y a la presunción de inocencia". Pode-se encontrar uma boa apresentação histórica em: VÁZQUEZ SOTELO, J.L. Presunción de inocencia del imputado e íntima convicción del tribunal (Estudio sobre la utilización del imputado como fuente de prueba en el proceso penal español), Barcelona: Ed. Bosch, 1984; TOMÁS Y VALIENTE, F. In dubio pro reo, libre apreciación de la prueba y presunción de inocencia, Revista Española de Derecho Constitucional, $\mathrm{n}^{\circ}$ 20, 1987; VEGAS TORRES, J. Presunción de inocencia y prueba en el proceso penal, Madrid: La Ley, 1993, 13-35 OVEJERO PUENTE, A. Ma ${ }^{\text {a }}$ Constitución y derecho a la presunción de inocencia, Valencia: Tirant lo Blanch, 2006, 21-71. No âmbito internacional, a presunção de inocência foi reconhecida, sob a influência do pensamento iluminista, no artigo 9.2. da Declaração do Homem e do Cidadão, em 1789: "Todo homem é considerado inocente até ser declarado culpado e, se julgar indispensável prendê-lo, todo rigor desnecessário à guarda da sua pessoa deverá ser severamente reprimido pela lei" (sobre as referências iluministas no âmbito penal vid. BECCARIA, C. Dei delitti e delle pene, Milano: Mondadori, 1764, 1991, cap. XVI, p. 54 e, sobre a influência de Beccaria no pensamento iluminista francês, ESMEIN, A. Histoire de la procédure criminelle en France: et spécialement de la procédure inquisitoire depuis le XIIIe siècle, L. Larose et Forcel, Paris, 1882, p. 364). Por sua parte, o artigo 11.1 da Declaração Universal dos Direitos Humanos, aprovada pela Assembleia Geral das Nações Unidas em 1948, estabelece que: “Todo homem acusado de um ato delituoso tem direito de ser presumido inocente até que a sua culpabilidade tenha sido provada de acordo com a lei, em julgamento público no qual lhe tenham sido asseguradas todas as garantias necessárias à sua defesa". O artigo 14.2 do Pacto Internacional dos Direitos Civis e Políticos, aprovado pela Assembleia Geral das Nações Unidas de 1966, dispõe que: "Qualquer pessoa acusada de um delito tem direito a que se presuma a sua inocência até que se prove a sua culpa conforme a lei". O artigo 8.2 da Convenção Americana sobre Direitos Humanos, conhecida como Pacto de São José da Costa Rica, estabelece que: "Toda pessoa acusada de um delito tem direito a que se presuma sua inocência, enquanto não for legalmente comprovada sua culpa". O artigo 6.2 do Convênio Europeu para a Proteção dos Direitos Humanos e das Liberdades Fundamentais de 1950, regula que "Qualquer pessoa acusada de uma infração presume-se inocente enquanto a sua culpabilidade não tiver sido legalmente provada". E quase idêntica redação tem, finalmente o artigo 48.1 da Carta dos Direitos Fundamentais da União Europeia: "Todo o arguido se presume inocente enquanto não tiver sido legalmente provada a sua culpa". 
primeira jurisprudência que a presunção de inocência reconhecida no texto constitucional supunha a constitucionalização do in dubio pro reo, tradicionalmente presente no direito processual penal em sede legislativa ${ }^{3}$.

A partir daí, a abundante jurisprudência sobre a presunção de inocência, tanto do Tribunal Constitucional como do Tribunal Supremo, assim como a dogmática processual e penal, que neste ponto seguiu de forma pouco crítica e sem colocar em dúvida a doutrina desenvolvida jurisprudencialmente, deram forma a um direito à presunção de inocência de caráter poliédrico. Em ocasiões poderia parecer inclusive que o maior reconhecimento à importância desse direito se levasse a cabo ao lhe dotar de cada vez mais facetas; isto é, quanto mais numerosos fossem os aspectos processuais que fossem predeterminados por ele.

Pois bem, o objeto deste trabalho não é de realizar uma análise teórica acerca, por exemplo, do caráter de falsa presunção da presunção de inocência ${ }^{4}$. Pretendo proceder, mais precisamente, a um exercício de metajurisprudência, analisando as diversas facetas do poliédrico direito

3 Mais tarde, como veremos, o próprio Tribunal modificou a sua doutrina sobre a relação entre a presunção de inocência e o princípio in dubio pro reo.

4 O que foi assumido de forma geral por parte da doutrina espanhola (vid. ao respeito: VÁZQUEZ SOTELO, J.L., op. cit., pp. 268-279: ROMERO ARIAS, E. La presunción de inocencia, Aranzadi, Pamplona, 1985, p. 38 ss.). Com efeito, uma norma que estabelece uma presunção tem a forma de "Se está provado A, presuma-se B”. A é o fato básico da presunção. B é o fato presumido. Se a presunção é iuris tantum, será possível derrotá-la em caso de que se prove que, ainda que tenha ocorrido $\mathrm{A}$ não tenha ocorrido $\mathrm{B}$, mas a não ocorrência de $\mathrm{B}$ deverá ser provada para derrotar a presunção. Se a presunção é iuris et de iure, uma vez provada a ocorrência de A, B será presumido e aceito no raciocínio sem possibilidade de prova contrária (ao respeito, vid., por todos: WRÓBLEWSKI, J. Structure et fonctions des présomptions juridiques, en Perelman, Ch. y Foriers, P.: Les présomptions et les fictions en Droit, Bruxelles: Bruylant, 1974: 48 e MENDONCA, D. Presunciones, Doxa, no 21, vol. 1, 1998, p. 92). Mas resulta que na chamada presunção de inocência não existe nenhum fato básico, A, a partir de cuja prova se desencadeie a presunção, o que permitiria duvidar de que esta seja uma norma de presunção. A jurisprudência do Tribunal Constitucional e do Tribunal Supremo, por outro lado, veio considerando a presunção de inocência como uma verdadeira presunção iuris tantum (una boa representação das teses jurisprudenciais pode ser encontrada em: MONTAÑÉS PARDO, M.A. La presunción de inocencia. Análisis doctrinal y jurisprudencial, Pamplona: Aranzadi, 1999. p. 43-44). Vid., no mesmo sentido que o TC y el TS: LUZÓN CUESTA, J.M ${ }^{\mathrm{a}}$. La presunción de inocencia ante la casación, Madrid: Colex, 1991. p. 13-14. Cfr. também o dito na nota 17, mais abaixo. 
no qual a doutrina, em especial a do Tribunal Constitucional, transformou a presunção de inocência. Sustentarei que muitas dessas facetas do poliedro são absolutamente irrelevantes: ao já estarem protegidas por outros direitos fundamentais, a situação jurídica do cidadão não variaria se o desenho da presunção de inocência não as incluísse. Por outro lado, também sustentarei que a operatividade como garantia processual da presunção de inocência exige dispor de um standard de prova intersubjetivamente controlável, o que hoje estamos longe de ter.

\section{As DISTINTAS FACETAS DA PRESUNÇÃO DE INOCÊNCIA}

Como acabo de indicar, a presunção de inocência se configura, em seu desenvolvimento jurisprudencial como um apanhado de direitos, processuais e extraprocessuais, que constituem as distintas facetas da presunção $0^{5}$ e que merecem uma atenção detalhada. Analisarei criticamente cada uma dessas facetas e alguns dos problemas que elas apresentam.

\subsection{A DiMENSÃo EXTRAPROCESSUAL DA PRESUNÇÃo DE INOCÊNCIA}

Além dos aspectos estritamente processuais ${ }^{6}$ que são declarados inerentes à presunção de inocência, existiria também como direito fora do processo judicial. Com efeito, o Tribunal Constitucional estabeleceu que a presunção de inocência também

STC 111/1999.

6 É preciso advertir que os aspectos processuais da presunção de inocência se apresentaram inicialmente na estrita margem do processo penal, mas hoje se admite de forma geral que não se esgotam nele, senão que abarcam a todo o processo "onde se trate da aplicação de sanções, ainda que não sejam penais" (VÁZQUEZ SOTELO, J.L., op. cit., p. 300; tradução livre da tradutora - de agora em diante, TLT; também, entre outros: GIMENO SENDRA, J.V. Los derechos de acción penal, al juez legal y de defensa y sus derechos instrumentales, in Cobo del Rosal (dir.): Comentarios a la legislación penal, tomo I, Madrid: Edersa, 1982. 189; RAMOS MÉNDEZ, F. El proceso penal. Lectura constitucional, Barcelona: Ed. Bosch, 1988, p. 15; PEDRAJAS MORENO, A. Despido y derechos fundamentales. Estudio especial de la presunción de inocencia, Madrid: Trotta, 1992, p. 235 ss.). No âmbito jurisprudencial, assim foi também estabelecido pela STC 13/1982, a que outras muitas seguiram. 
"opera em situações extraprocessuais e constitui o direito a receber a consideração e o tratamento de não-autor ou partícipe em fatos de caráter delituoso ou análogos a esses e determina, em consequência, que o direito a que não se apliquem as consequências ou os efeitos jurídicos atribuíveis a fatos de tal natureza às relações jurídicas de todo tipo "(STC 109/1986, F. J. $\left.1^{\circ}\right)^{7}$.

As situações extraprocessuais nas quais a presunção de inocência seria aplicável poderiam ser de dois tipos: aquelas que implicam o poder sancionador do Estado, i.e., o procedimento administrativo sancionador, e as relações entre particulares. Em princípio, poderia parecer não apresentar maiores problemas o primeiro deles, pela evidente analogia dele com o processo penal. Por outro lado, resulta mais discutível a extensão do direito à presunção de inocência às relações entre particulares.

O âmbito em que mais amplamente a presunção de inocência encontrou-se aplicável entre particulares é no tratamento informativo e jornalístico.

Nele, os meios de comunicação teriam a obrigação de tratar qualquer cidadão como não-autor de um ilícito e, como pessoa objeto de informação de direito, o direito de ser tratada como tal. Em outros termos, os meios de comunicação são proibidos de atribuir a uma pessoa a comissão ou participação de um delito (ou infração não-penal) até que se produza sentença condenatória ao respeito ${ }^{8}$.

7 STC $109 / 1986$, F.J. $1^{\circ}$ (tradução livre). Ainda que o ponto não esteja isento de discussão, boa parte da dogmática seguiu também a doutrina jurisprudencial acerca do alcance extraprocessual da presunção de inocência. Vid., por exemplo: LUZÓN CUESTA, J.Ma ., op cit., p. 13.

8 Veja-se no que se refere ao Tribunal Constitucional, entre outras, a STC 219/1992 e, por parte do Tribunal Supremo, a STS de 16 de março de 1990. A aplicabilidade da presunção de inocência a âmbitos extraprocessuais é um dos argumentos utilizados por Ovejero Puente para negar-lhe o caráter de garantia processual (OVEJERO PUENTE, op. cit., p. 87 e ss). O outro argumento é de caráter constitucional e não processual do direito à presunção de inocência. O alcance do primeiro argumento será discutido em seguida no texto. O segundo argumento parece, a meu entender, uma clara confusão entre o caráter processual ou substantivo de uma norma e sua hierarquia normativa. Neste sentido, a localização da norma na fonte constitucional nada diz acerca de seu caráter processual ou substantivo. 
No entanto, não surpreende, em minha opinião, que a aplicação da presunção de inocência nestes âmbitos por parte da jurisprudência se reduza a um mero reconhecimento retórico, visto que a própria Constituição oferece proteções mais operativas através da aplicação de outros direitos, em especial, do direito à honra e à própria imagem, de maneira que a adição do direito à presunção de inocência não supõe uma maior proteção e cai, pois, na irrelevância. Assim reconheceu o próprio Tribunal Constitucional, que na sua sentença 166/1995 declara expressamente que, apesar do reconhecimento na STC 109/1986 da dimensão extraprocessual da presunção de inocência, esta

"não constitui por si mesma um direito fundamental distinto ou autônomo daquele que emana dos artigos 10 e 18 da Constituição, de tal modo que há de ser o desrespeito desses preceitos, e especificamente do artigo 18, o que sirva de base a sua proteção através do recurso de amparo". ${ }^{9}$

Em resumo, é o próprio Tribunal quem declara a irrelevância jurídica dessa dimensão extraprocessual da presunção de inocência que ele mesmo construiu ${ }^{10}$. Em minha opinião, sem embargo, poderia restar ainda um espaço para a aplicação da presunção de inocência nessas hipóteses. Se se sustenta que o recurso ao direito à honra, por exemplo, é proteção suficiente nesses casos, a pergunta relevante seria essa: por que afeta a honra de Pedro a publicação por um meio de comunicação de que ele cometeu um homicídio antes de que ele tenha sido por ele condenado? O meio de comunicação poderia alegar que a honra de Pedro não lhe protege se cometeu o homicídio. Mas, precisamente aqui aparece a função da presunção de inocência: a honra de Pedro é afetada porque até o momento da condenação ele deve ser presumido inocente, i.e., tratado como inocente. Desse modo, dizer que o direito fundamental afetado é o direito à honra não excluiria que houvesse um espaço para a aplicabilidade da presunção nestes casos, senão que, melhor dizendo, a presunção lhe faria as vezes de um pressuposto.

9 STC 166/1995 (tradução livre).

10 Para uma crítica, a meu entender, não convincente, vid.: OVEJERO PUENTE, op. cit., p. 365-374. 


\subsection{A DIMENSÃO PROCESSUAL DA PRESUNÇ̃̃o DE INOCÊNCIA}

O âmbito principal de aplicação da presunção de inocência é o processo judicial, em especial (ainda que não unicamente, como temos visto), na jurisdição penal. Nesse contexto, a jurisprudência desenvolveu quatro facetas principais do direito em exame, ou, se se prefere, decompôs o macro-direito à presunção de inocência em direitos mais específicos os quais se circunscrevem a quatro âmbitos de aplicação diferentes ${ }^{11}$. Vejamos.

\subsubsection{A PRESUNÇÃO DE INOCÊNCIA COMO PRINCÍPIO INFORMADOR DO PROCESSO PENAL}

Tem-se sustentado reiteradamente, quase como um lugar comum, que a presunção de inocência tem um papel determinante como princípio informador de todo o processo penal. Assim, o Tribunal Constitucional declarou que a presunção de inocência "serve de base a todo procedimento criminal e condiciona a sua estrutura, constituindo um dos princípios cardiais do Direito Penal contemporâneo, em suas facetas substantiva e formal"12. Neste sentido, a presunção de inocência atuaria "como limite ao poder legislativo e como critério condicionador das interpretações das normas vigentes"13 (STC109/1986, F.J. 1o) a respeito do processo penal.

Parece, pois, que a interpretação jusrisprudencial constitucional do artigo 24.2 da Constituição espanhola extrai deste duas normas de obrigação direcionadas aos poderes públicos estatais. Por um lado, uma norma cujo destinatário é o legislador ordinário e que lhe impõe regular de determinado modo o processo penal. Por outro, uma norma direcionada

11 O próprio Tribunal Constitucional espanhol percebeu e declarou expressamente que se trata de regras e direitos distintos, que estariam constitucionalizados mediante o nome comum de 'presunção de inocência'. Vid. STC 66/1984, F.J. $1^{\circ}$.

12 STC 111/1999, FJ $2^{\circ}$ (tradução livre). Ver também, entre muitos, VEGAS TORRES, J. op. cit., p. 35 ss.; ANDRÉS IBÁÑEZ, Perfecto. Acerca de la motivación de los hechos en la sentencia penal. Doxa: Cuadernos de Filosofia del Derecho, n. 12 , p. $257-299$, 1992, p. 274 ; poder-se-ia dizer que, neste ponto, tanto a jurisprudência espanhola como boa parte da doutrina seguiram a tese da denominada Escola clássica do direito penal, encabeçada na Itália por Carrara. Vid., o respeito, uma boa apresentação em VEGAS TORRES, J. op. cit. p. 20 ss.

STC109/1986, F.J. 1o (tradução livre). 
aos juízes e tribunais lhes obrigando a selecionar interpretações dos dispositivos processuais que sejam compatíveis com a presunção de inocência.

No entanto, deixando de lado considerações mais gerais acerca da duvidosa capacidade reguladora dos princípios ${ }^{14}$, as seguintes perguntas resultam relevantes aqui: quais são os limites que esse princípio informador impõe ao legislador na hora de regular o processo penal? Que condicionantes ele impõe aos juízes e tribunais ao momento de selecionar interpretações dos dispositivos processuais vigentes? Entendo que cabem duas respostas a essas perguntas: ou bem esses limites e condicionantes são independentes das outras facetas processuais da presunção de inocência - que serão expostas e analisadas à continuação - ou bem não são mais que o outro lado da moeda dessas últimas.

Com efeito, como se verá em seguida, o desenvolvimento jurisprudencial e dogmático da presunção de inocência extraiu dela uma boa quantidade de direitos subjetivos do cidadão, que desempenhariam o papel de garantias processuais. Uma vez determinada a lista das garantias processuais, constitucionalmente protegidas, cabe entender que estas são precisamente as que constituem um limite ao legislador em sua competência reguladora do processo penal: o legislador não poderia desenhar o processo penal de forma a se violar algum desses direitos subjetivos considerados fundamentais. O mesmo cabe dizer dos limites impostos aos juízes e tribunais em suas decisões interpretativas. Mas, se é assim, a faceta da presunção de inocência como princípio informador do processo penal se reduz à aplicação desses mesmos direitos e, portanto, não é uma faceta que independe deles. Recorrendo às modalidades hohfeldianas ${ }^{15}$, pode-se dizer que o direito subjetivo do cidadão, por exemplo, de não ser condenado em um processo penal se não há prova de sua autoria, é correlativo ao dever dos juízes de não condenar sem essa prova e ao

14 Não posso aqui abordar esse espinhoso tema por razões de espaço. Apenas direi que, se os princípios são normas cujas condições de aplicação estão parcialmente abertas, então não podem ser aplicados para resolver um caso até que se tenham fechado as suas condições de aplicação, i.e., transformados em regras.

15 Vid. HOHFELD, W.N. Some Fundamental Legal Conceptions as Applied to Judicial Reasoning, Yale Law Journal, 16, $\mathrm{n}^{\circ} 23$. Citado por la traducción castellana de Carrió, G.: Conceptos jurídicos fundamentals, México, D.F.: Fontamara, 1913, 1992. p. 47. 
dever do poder legislativo de não regular o processo penal de maneira que essa condenação seja possível. O mesmo tipo de raciocínio pode ser realizado sobre cada uma das garantias processuais que comumente se extraem da presunção de inocência ${ }^{16}$.

\subsubsection{A PRESUNÇÃO DE INOCÊNCIA COMO REGRA DE TRATAMENTO PROCESSUAL}

Trata-se de uma regra que rege o tratamento que deve ser dado a qualquer pessoa que se veja imersa como sujeito passivo de um processo penal. Assim, a presunção de inocência como regra de tratamento impõe tratar o imputado como se fosse inocente (STC 66/1984, F. J. 10) até que contra ele se emita sentença que declare a sua culpabilidade. Nesta faceta da presunção de inocência à qual apelam expressamente a maioria de declarações internacionais de direitos e de textos constitucionais (com exceção do espanhol, que se limita a estabelecer o direito à presunção de inocência, sem maiores especificações).

A garantia processual que a presunção de inocência outorga aqui supõe que o Estado não pode tratar o cidadão de outra forma a não ser como inocente até que o juiz ou tribunal, depois de um processo com todas as garantias, declare provada a sua culpabilidade ${ }^{17}$. Nada se

16 Também colocam em discussão, precisamente, o caráter da presunção de inocência como princípio informador de todo o processo penal, ainda que por razões parcialmente distintas às já expostas aqui, mas não incompatíveis com elas: CHIAVARIO, M. Presunzione d'innocenza e diritto di difesa nel pensiero di Francesco Carrara, en AA.VV.: Francesco Carrara nel primo centenario della morte. Atti del convegno internazionale, Lucca-Pisa, 2-5 giugno 1988, Milano: Giuffre, 1991, p. 614-615; FERNÁNDES LÓPEZ, M. Prueba y presunción de inocencia, Madrid: Iustel, 2005, p. 122-123.

Observe-se, em linha do sinalizado na nota 4 , que não tem sentido sequer pensar o direito à presunção de inocência como regra de tratamento na forma de regra de presunção. Não se trata que, dado um fato A, deva-se presumir um fato B (i.e., a inocência). E menos ainda que esta presunção, como sustenta uma parte da doutrina e da jurisprudência, seja uma presunção iuris tantum. Como regra de tratamento, o que permitiria destruir a presunção? O que é que há de ser presumido? Mais precisamente, parece ter forma de ficção jurídica: a regra estabelece que, até o momento em que recaia sentença condenatória, o acusado deve ser tratado como se fosse inocente. A discussão sobre a compatibilidade desta regra com as medidas cautelares no processo penal seria, então, um debate sobre o âmbito de aplicação da referida ficção, 
diz, neste ponto, a respeito das condições nas quais estará justificada e procedente essa declaração de culpabilidade: isso será objeto de outros direitos subjetivos vinculados à presunção de inocência como regra probatória e como regra de julgamento. A única coisa que a regra de tratamento impõe é que o Estado (inclusive o próprio juiz da causa) não pode submeter o imputado a nenhum tratamento nem tomar qualquer decisão no curso do processo que suponha a antecipação da condenação e, em consequência, da pena ${ }^{18}$.

Aqui muitas questões de grande interesse prático se apresentam: por exemplo, em que momento se inicia a proteção dessa regra? Quando ela se encerra? Alguns autores afirmam que a proteção ao presumidamente inocente outorgada por essa regra de tratamento tem fim com a primeira sentença condenatória ${ }^{19}$; outros, de outra parte, sustentam que a regra deve seguir sendo aplicada até o momento em que a sentença condenatória

i.e., sobre quais são as hipóteses nas quais procede aplicá-la e quais são as hipóteses nas quais a regra não é aplicável e, portanto, podem ser aplicadas medidas cautelares que não tratem o acusado como se fosse inocente. Voltarei a esse ponto, no texto, ao final desta epígrafe.

18 Seria possível sustentar-se que a prisão preventiva, como qualquer outra medida cautelar, não supõe em qualquer caso uma antecipação da pena. Aquela implica, efetivamente, uma privação de liberdade, mas não toda privação de liberdade é uma pena no sentido estrito. Assim é, por exemplo, no caso das medidas de segurança, internações forçosas por razões sanitárias etc. A pena teria sempre como uma de suas características definitórias a reprovação, coisa que não se daria no caso da prisão preventiva. Não é objeto deste trabalho discutir as distintas teorias sobre a noção de pena ou castigo e sua justificação. Sem embargo, creio que ainda que se entendera desse modo retribucionista a pena, os problemas sinalizados nessa epígrafe não são resolvidos. O ponto de partida principal, em minha opinião, é determinar o que significa "tratar como se fosse inocente". Pois bem, estimo que a resposta é relativa ao próprio sistema jurídico: há que se dar ao acusado o mesmo tratamento que seria consequência da declaração de inocência no processo e esse mesmo trato é que se deve dar ao acusado até que se lhe recaia sentença condenatória. Se isso é assim, resulta claro que a declaração de inocência, como tal, não tem como consequência em nossos sistemas (ainda que claro, isso é contingente) nenhum tipo de medida de segurança. Estas poderiam ser tomadas, em seu caso, mas não são em sentido estrito uma consequência jurídica da declaração de inocência, senão, em seu caso, de outros antecedentes.

VEGAS TORRES, op. cit., p. 41. 
transite em julgado ${ }^{20}$. Contudo, é claro que o problema principal que se apresenta é o da compatibilidade da presunção de inocência com as medidas cautelares no decorrer do processo penal e, em especial, com a prisão preventiva. Em outros termos, aqui se apresenta o dilema entre a garantia da segurança dos demais cidadãos e a liberdade do acusado que, sem possuir decisão condenatória, tem todos os direitos vinculados ao fato de que é o próprio Estado que pretende impor medidas cautelares sem que já lhe tenha declarado culpado ${ }^{21}$. O dilema foi objeto de uma ampla atenção doutrinária desde a época romana, com posturas que vão desde abolicionistas da presunção de inocência, vinculadas a um direito penal autoritário ${ }^{22}$, até as abolicionistas da prisão preventiva ${ }^{23}$. No meio do caminho, situam-se a teses compatibilistas majoritárias que, em geral pretendem fazer compatível uma prisão preventiva muito restritiva com a vigência da presunção de inocência como regra de tratamento processual ${ }^{24}$.

20 FERRAJOLI, L. (1998): Diritto e ragione. Teoria del garantismo penale, Roma-Bari: Laterza, p. 559.

21 Vid., por todos, MONTESQUIEU. De l'esprit des lois, Garnier Frères Libraires-Éditeurs, Paris, 1748, 1878, livro XII, caps. 1-4, p. 171-175; e uma apresentação moderna em HASSEMER, W. Die Voraussetzungen der Untersuchungshaft, Der Strafverteidiger, $\mathrm{n}^{\mathrm{o}}$ 1; citado por la traducción castellana de Ziffer, P.: Los presupuestos de la prisión preventiva, in Hassemer, W.: Crítica al derecho penal de hoy, Buenos Aires: Ad Hoc, 1984, 1995, p. 105 e ss.

22 Veja-se uma apresentação em FERRAJOLI, op. cit., p. 564-6 e a bibliografia lá citada.

23 Poder-se-ia citar aqui Ferrajoli, como defensor das teses abolicionistas da prisão preventiva. Vid. FERRAJOLI, op. cit., p. 566-572. Impedir o uso da prisão preventiva é, para esse autor, a melhor maneira de evitar cair no habitual abuso da mesma. Sem embargo, a argumentação desenvolvida por Ferrajoli deixa algumas possibilidades abertas que, como bem sinalizou Pastor, permitiriam situá-lo entre os defensores das teses compatibilistas mais restritivas da presunção de inocência (PASTOR, D. Las garantías de libertad del imputado, en AA.VV.: Garantismo y crisis de la justicia, Universidad de Medellín, Medellín: 2010, p. 131 e ss.).

24 Entre os autores compatibilistas, encontramos boa parte dos clássicos iluministas, Vid por exemplo, HOBBES, T. Leviatán, trad. a cargo de Mellizo, C., Madrid: Alianza Universidad, 1651, 1989, § XXVIII, p. 249, 252 y BECCARIA, op. cit., § XIX, p. 62. E em nossos dias, apenas para citar alguns nomes: ILLUMINATI, G. La presunzione d'innocenza dell'imputato, Bologna: Zanichelli, 1979, p. 33; HASSEMER, op. cit., p. 115-6; FERNÁNDEZ LÓPEZ, op. cit. p. 123-138; y PASTOR, op. cit., p. 131 ss. 
Não é o objeto de interesse central deste trabalho a análise das distintas estratégias para abordar o dilema que se apresenta entre a garantia da segurança e a garantia da presunção de inocência como regra de tratamento processual. Por isso, não me estenderei sobre esse ponto. Apenas gostaria de ressaltar que, a meu entender, as teses compatibilistas (distintas entre elas no que se refere à quantidade e severidade das restrições impostas à procedência da prisão preventiva) apresentam mal a questão se seu ponto de partida é a negação do dilema e, portanto, a compatibilidade entre as duas garantias estatais.

Vamos por partes. Três são as hipóteses em que habitualmente considera-se que procederia adotar a prisão preventiva do imputado como medida cautelar no decorrer do processo penal: o perigo de reincidência, a proteção de provas e o perigo de fuga do acusado. Resulta extremamente difícil, para não dizer conceitualmente impossível, sustentar a argumentação de que o imputado é tratado como se fosse inocente e, ao mesmo tempo, que é submetido à prisão para evitar que reincida na comissão do delito. Evidentemente, para reincidir é preciso que já tenha incidido nele, que é exatamente o que a presunção de inocência obriga a presumir que não se fez. O caso da proteção de provas é o mais duvidoso. Se trata aqui de evitar que o imputado manipule ou faça desaparecer provas que lhe sejam desfavoráveis. Ainda que para ter interesse em manipular ou fazer desaparecer provas não seja necessário que o imputado seja o autor do delito do qual é acusado, creio, sim, que de forma geral o argumento pressupõe precisamente o que a presunção de inocência nega: que é autor do delito e, por isso, fará o possível para evitar que essa circunstância possa ser provada no processo. Sobre o perigo de fuga, creio que basta dizer que o inocente não foge, senão viaja. Os próprios termos delatam o argumento ruim. Por outro lado, como já advertira Voltaire há mais de duzentos anos, cabe a possibilidade de que não seja a autoria do delito o que incentiva o imputado a fugir, mas o medo de ser submetido à prisão preventiva sem poder se defender ${ }^{25}$. Se a prisão preventiva não existisse, o imputado poderia não ter motivos para fugir, ao menos até o momento imediatamente prévio

25 VOLTAIRE, Commentaire sur le livre Des délits et des paines, par un advocat de province, Paris, 1766, p. 111-112. 
à condenação. Até então, seu máximo interesse seria o de se defender das acusações feitas contra ele ${ }^{26}$.

Não quero entrar na discussão acerca da justificabilidade da prisão preventiva nestas ou noutras hipóteses. Meu único interesse é sinalizar que a situação seria melhor descrita se aqueles que defendem o caráter legítimo de se adotar algumas hipóteses da prisão preventiva (ou outras medidas cautelares) durante o processo sustentassem que, nesses casos, o direito à presunção de inocência como regra de tratamento processual é vencido por argumentos mais fortes, privilegiando-se, assim, o lado do dilema que atende a proteção da segurança cidadã. Falar de limites no âmbito da aplicação da presunção de inocência como regra de tratamento processual parece-me uma melhor apresentação conceitual da situação a pretender encontrar uma compatibilidade entre ser tratado como inocente e concomitantemente ser posto em prisão. Assim apresentado, o debate entre abolucionistas (da prisão preventiva ou da presunção de inocência) e compatibilistas seria, melhor dizendo, um debate entre os limites da presunção de inocência como regra de tratamento processual, i.e., se pode ser derrotada e, nesse caso, sob quais condições.

\subsubsection{A PRESUNÇÃO DE INOCÊNCIA COMO REGRA PROBATÓRIA}

Seguindo o desdobramento da presunção de inocência em direitos mais específicos, realizado pela doutrina e pela jurisprudência, encontramos mais uma faceta processual dela. Trata-se da dimensão da presunção de inocência como regra probatória ${ }^{27}$. O desenvolvimento desta dimensão da presunção de inocência foi realizado na Espanha,

26 FERRAJOLI, op. cit., p. 569-570.

27 Seguirei a distinção proposta por Fernández López entre a faceta da presunção de inocência como regra probatória e a faceta como regra de julgamento sobre os fatos (FERNÁNDEZ LÓPEZ, op. cit. p. 139 ss.). Evidente, em um sentido pode-se dizer que ambas são aspectos da prova no processo, mas creio que sua separação permite perceber com maior clareza que a primeira versa sobre a prova como atividade no processo judicial, enquanto que a segunda versa sobre a prova como resultado daquela atividade, isto é, sobre a declaração de fatos provados a ser realizada na sentença judicial. Sobre a distinção entre prova como atividade e como resultado, vid. FERRER BELTRÁN, J. Prueba y verdad en el derecho, $2^{\text {a }}$ ed., Madrid: Marcial Pons, 2003, p. 40-3. 
fundamentalmente, pela sentença do Tribunal Constitucional 31/1981. Nesta sentença, o Alto Tribunal declarou que o direito à presunção de inocência tem implicações diretas sobre como deve ser o procedimento probatório que possa dar lugar à derrota da própria presunção, mediante a sentença de culpabilidade. Dito de outra maneira, não basta que recaia sentença que declare a condenação para que a presunção de inocência ceda: essa declaração deve ser a conclusão de um procedimento probatório com todas as garantias processuais. Esta parece ser uma razoável interpretação de alguns tratados internacionais que, como o Pacto de San José da Costa Rica (art. 8.2), estabelecem que "toda pessoa acusada de um delito tem direito a que se presuma a sua inocência até que se prove a sua culpabilidade conforme a lei" ${ }^{28}$ (o grifo é meu). O mesmo se pode dizer do artigo 6.2 do Convênio Europeu para a Proteção dos Direitos Humanos e das Liberdades Fundamentais, que dispõe que "toda pessoa acusada de uma infração se presume inocente até que sua culpabilidade haja sido legalmente declarada"29 (o grifo é meu).

Assim, a STC 31/1981, da que partem e a qual seguem todos os desenvolvimentos jurisprudenciais posteriores, sustenta que a sentença que declare a culpabilidade do imputado e, portanto, a derrota da presunção de inocência deve cumprir uma série de requisitos procedimentais probatórios para que a presunção seja, efetivamente, vencida e não-violada: a) deve ser a conclusão de um procedimento no qual tenha ocorrido, ao menos, uma mínima atividade probatória; b) que possa ser considerada prova de autoria; c) produzida pela acusação; d) praticada em um juízo oral; e, e) que tenha sido obtida respeitando todas as garantias constitucionais e legais.

Sem que isso signifique objeção às cinco condições postas como expressão do que seja o devido processo penal, parece sim mais que discutível que elas façam parte do exigido pelo direito à presunção de inocência, ao menos em sua faceta de regra probatória ${ }^{30}$. Se, por outro lado,

28 Tradução livre de: "Toda persona acusada de un delito tiene derecho a que se presuma su inocencia mientras no se pruebe su culpabilidad conforme a la ley". Tradução livre de: "Toda persona acusada de una infracción se presume inocente hasta que su culpabilidad haya sido legalmente declarada".

30 Vegas Torres (op. cit., p. 43-5) apresenta um argumento interessante neste ponto e parcialmente distinto ao sustentado pelo Tribunal Constitucional. 
afirma-se que o direito à presunção de inocência como regra probatória abarca todas essas subregras, então é fácil observar que muitas delas se tornam garantias irrelevantes, uma vez que já estão protegidas por outros direitos ou outras facetas da presunção de inocência. Para demonstrar isso com clareza, convém analisar cada um dos referidos requisitos.

A) e B) se sobrepõem claramente com a faceta da presunção de inocência como regra de julgamento. Como se verá em seguida, se dispomos de um standard de prova, o cumprimento do mesmo já supõe a atenção às exigências A) e B). Isso resulta ainda mais evidente a partir do momento em que tanto o Tribunal Constitucional ${ }^{31}$, como o Tribunal Supremo $^{32}$ adicionaram o requisito de que a mínima atividade probatória sobre a autoria seja suficiente para apoiar a decisão condenatória ${ }^{33}$. Determinar quando a prova de autoria é suficiente para justificar a condenação é precisamente a função de um standard de prova. Portanto, uma vez que se disponha o standard de prova, esses requisitos ficam subsumidos nele e adicioná-los aqui resulta totalmente supérfluo. Se, por outro lado, não se dispõe de um standard de prova que estabeleça quando a prova é suficiente, a mera remissão à suficiência não produz garantia alguma ao cidadão. Voltarei, em todo caso, a este ponto na epígrafe seguinte.

D), por sua parte, (i.e., que a prova seja praticada no juízo oral) é um requisito de fiabilidade da prova. Que se exija que as provas sejam praticadas no juízo tem sentido como instrumento para possibilitar ou facilitar, em cada caso, a imediação, a publicidade e, especialmente, o contraditório na prática das provas. E todas elas são exigências encaminhadas a melhorar a fiabilidade da prova que se adiciona ao processo e

Assim, o autor sustenta, a presunção de inocência não atribui per se todos esses direitos ao acusado. Trata-se, melhor dizendo, de uma norma constitucional em branco que converte em direito fundamental o cumprimento das regras probatórias legais. Isso é o que significaria que a sentença condenatória deve ser a conclusão de um procedimento probatório conforme à lei. Mas a constituição delegaria à lei a determinação de qual é esse procedimento probatório. Em todo caso, pelas razões que exporei em seguida no texto, tampouco esse argumento me parece convincente.

31 STC 259/1994, F.J. 2o, por exemplo.

32 STS de 16 de junho de 1992, entre outras muitas.

33 VEGAS TORRES, op. cit., p. 129 e ss; MIRANDA ESTRAMPES, M. La mínima actividad probatoria en el proceso penal, Bosch, Barcelona, 1997, p. 596 ss. 
a uma melhor valoração dela. Em especial, a prática da prova em juízo oral é um requisito cuja função é de possibilitar o contraditório na sua própria prática; a capacidade de superar as objeções e as contra-provas é, precisamente, um dos critérios fundamentais para outorgar fiabilidade à prova $^{34}$. Portanto, entendo que esse requisito D) resta também subsumido às exigências do standard de prova, por um lado, e do devido processo legal, por outro (na medida em que o devido processo deve ser tal que permita superar o standard de prova estabelecido para ele).

O requisito E) (i.e., a exclusão das provas ilícitas como fundamento para a condenação penal) não tem nada a ver, em minha opinião, com a presunção de inocência. A exclusão da prova ilícita é consequência da proteção de outros direitos fundamentais, como o segredo das comunicações ou a inviolabilidade do domicílio ou da correspondência, por exemplo. Uma vez decidida a exclusão, o elemento do juízo não é uma prova nesse processo. Por isso, não pode ser usado para fundamentar qualquer decisão, mas este não é um efeito da presunção de inocência ${ }^{35}$.

34 Veja-se STC 209/2001, F.J. $4^{\text {o }}$, tanto para a fundamentação desse requisito como para as exceções que o próprio Tribunal reconhece, nas que seriam admissíveis provas antecipadas e pré-constituídas. Pode-se ver uma apresentação geral em: FERNÁNDEZ LÓPEZ, op. cit. p. 146-150.

35 Se se considera que a exclusão da prova ilícita é um efeito da presunção de inocência, não teria sentido excluir essa prova, como se faz na Espanha, quando surta efeitos favoráveis à defesa (se esta não é responsável pela ilicitude). De fato, no direito anglo-saxão e também em alguns outros países de civil law (como Itália ou Brasil, por exemplo) a regra geral é a admissibilidade da prova nesses casos. Também entre nós lhe recordaram diversos autores; vid., por exemplo, MIRANDA ESTRAMPES, M. La regla de exclusión de la prueba ilícita: historia de su nacimiento y de su progresiva limitación, Jueces para la Democracia, 47, 2003, p. 65; DE LA OLIVA SANTOS, A. Sobre la ineficacia de las pruebas ilícitamente obtenidas, Tribunales de Justicia, $\mathrm{n}^{\circ}$ 8-9, 2003, p. 10; e uma apresentação geral em GÓMEZ COLOMER, J.L. (ed.). Prueba y proceso penal. Análisis especial de la prueba prohibida en el sistema español y en el derecho comparado, Valencia: Tirant lo Blanch, 2008; ARMENTA DEU, T. La prueba ilícita (un estudio comparado), Madrid: Marcial Pons, 2009, p. 74-76. Entenda-se bem: não estou defendendo que a admissão da prova ilícita favorável à defesa vincularia de algum modo a regulação da admissibilidade dessa prova com a presunção de inocência: sustento que não tem sentido afirmar que a exclusão da prova ilícita é consequência da proteção da presunção de inocência e, ao mesmo tempo, excluir a prova favorável à defesa. 
Se isso é assim, da presunção de inocência como regra probatória somente fica $\mathrm{C}$ ), isto é, a atribuição do ônus da prova à acusação. Ainda que o ponto me pareça muito mais discutível que os anteriores, em minha opinião, tampouco resulta especialmente esclarecedor vincular a presunção de inocência com a atribuição à acusação ao ônus da prova. De fato, essa distribuição do ônus da prova pode derivar da regra geral, já vigente no processo romano, de que incumbe a quem afirma a ocorrência de um fato a sua prova e não a quem a nega (ei incumbit probatio qui dicit non qui negat $)^{36}$, regra esta que foi recebida em nosso ordenamento pelo artigo 1214 do código civil espanhol: "A prova das obrigações incumbe a quem reclama o seu cumprimento, e a da extinção àquele que a ela se opõe" (tradução livre).

Mais adiante voltarei sobre a concepção da presunção de inocência como regra probatória em sua função de regra sobre o ônus da prova. Pelo momento, quisera advertir que, entendida assim, produz-se a tendência de expandir o âmbito de aplicação da presunção de inocência a qualquer hipótese de distribuição de ônus da prova. Um caso claro desta confusa expansão pode ser encontrado no âmbito do processo do trabalho. Com efeito, especialmente ao que se refere ao direito disciplinar do trabalho e, em particular, das extinções contratuais por demissão, tanto o Tribunal Constitucional como o Tribunal Supremo e o extinto Tribunal Central do Trabalho desenvolveram uma doutrina oscilante a respeito do alcance ${ }^{37}$, mas estável no que se refere à aplicabilidade do direito à presunção de inocência. Pode ver-se, por exemplo, a STC 6/1988, que considera que seria contrário à presunção de inocência exigir do trabalhador a satisfação do ônus da prova sobre a inexistência da causa de demissão. E resulta muito clara também a sentença do Tribunal Central do Trabalho de 12 de novembro de 1985.

36 Vid. referências ao respeito em: FERRAJOLI, op. cit., p. 172, nota 47.

37 Discute-se aqui se a presunção de inocência seria aplicável entre particulares, i.e., entre empresário e trabalhador, ou bem se entra no jogo unicamente no momento da judicialização das relações de trabalho, no processo laboral. As linhas doutrinárias e jurisprudenciais não são constantes ao respeito, ainda que tendem progressivamente a optar por essa última opção. Ao respeito, vid. RODRIGUEZ-PIÑERO, M. Carga de la prueba y presunción de inocencia en el proceso de despido, Relaciones laborales: revista crítica de teoría y práctica, $\mathrm{n}^{\mathrm{o}}$ 8, 1990, p 6; PEDRAJAS MORENO, op. cit., p. 241 ss. 
“a presunção de inocência (...) nem se circunscreve aos âmbitos penais e laboral nem, dentro deste, à imputação de descumprimentos contratuais, senão a todos àqueles fatos que, sendo transcendentes ao correto processamento da questão litigiosa, estão submetidos às regras gerais que dispõem o ônus da prova (...)"38 (Grifei).

Como se pode observar com clareza nas referências e citações indicadas, a vinculação entre presunção de inocência e ônus da prova não apenas resulta desnecessária senão que também tende a produzir uma expansão do âmbito de aplicação da presunção de inocência a situações nas quais nada parece ter a ver com a inocência ou culpabilidade de qualquer das partes. Um caso muito claro é o da STC 13/1982, já citada, na qual se declara aplicável e violável a presunção de inocência no caso em que uma acusação não provada de homossexualidade do marido, no marco de um processo de medidas provisórias de separação matrimonial, haveria servido para atribuir a custódia dos filhos à mulher. Vale a pena citar uma parte da sentença:

"Pois bem, a Sentença da Audiência Provincial de Madrid de 1 de abril de 1981 afirma de maneira taxativa que em dita segunda instância se atribui ao marido homossexualidade, 'que não está provado, mas tampouco contraditado nos autos. Por tudo, pese aos defeitos da mãe provados, diante da gravidade da referida suspeita referido ao pai, convém continuar o atual estado de coisas, mantendo o auto do julgado ditado com data de 17 de março de 1978, deixando a guarda dos menores à mãe....

\section{(...)}

A realidade foi, pois, que a audiência, baseando-se em um fato que expressamente considera não provado dele extraiu consequências jurídicas que claramente limitam que ao pai pudera corresponder. Mas isso deve ser apreciado considerando que a sentença da $\mathrm{Au}$ diência Provincial de Madrid vulnerou o direito à presunção de inocência proclamado no art. 24, núm. 2 da Constituição espanhola e que ampara o recorrente"39 (grifei).

38 As mesmas teses podem ser encontradas na doutrina. Vid, por todos: ALONSO OLEA, M. y CASAS BAAMONDE, M.E. Derecho del trabajo, Madrid: Civitas, 1987, p. 404; PEDRAJAS MORENO, op. cit., p. 241 ss. 
Para concluir esse item: creio que há um erro interpretativo na doutrina majoritária sobre a presunção como regra probatória. Parte-se das disposições internacionais que regulam a presunção de inocência nesses termos: "Toda pessoa acusada de uma infração se presume inocente até que a sua culpabilidade tenha sido declarada conforme a lei”. E se considera, razoavelmente, que a cláusula "conforme a lei" supõe que não basta qualquer declaração judicial de culpabilidade, senão que esta deve haver sido o resultado de um processo judicial com todas as garantias processuais reconhecidas pelo direito. Até aqui não há qualquer problema. No entanto, o passo errôneo na argumentação é inferir que isso supõe que a própria presunção de inocência incorpora, em consequência, essas garantias, de modo que por arte dessa interpretação todas elas se constitucionalizam, adquirem caráter de direito fundamental. Não pretendo sustentar que esta é uma interpretação errônea ${ }^{40}$; mas que o erro está em supor que essa é a única interpretação possível. Uma interpretação alternativa passaria por considerar que o que o direito à presunção de inocência como regra probatória exige é que se tenha respeitado todas as garantias processuais reconhecidas pelo próprio ordenamento jurídico sem, por isso apenas, incorporá-las ao direito. Tratar-se-ia de uma remissão em branco às garantias que o ordenamento jurídico em seu conjunto tenha reconhecido em cada momento.

Vejamos através de outro exemplo: o artigo 25.2 da Constituição espanhola estabelece que "[o] condenado à pena de prisão que a estiver cumprindo gozará de direitos fundamentais deste Capítulo, com exceção dos que se vejam expressamente limitados pelo conteúdo da decisão condenatória, pelo sentido da pena e da Lei penitenciária”. Pois bem, observa-se uma remissão à Lei penitenciária a efeitos de se determinar as exceções ao gozo dos direitos fundamentais por parte dos condenados à pena de prisão. Mas isso não supõe, claro está, que as exceções que estabeleça a referida lei no momento $m 1$, convertam-se, por isso, em constitucionalizadas ou incorporadas ao referido artigo 25.2. Se fosse assim, essas já não poderiam ser modificadas mediante normas com status de legislação infraconstitucional, por efeito de hierarquia normativa. Do mesmo modo,

40 O que, para efeitos deste trabalho, me comprometeria com a tese forte da interpretação que não necessito, i.e., que há interpretações verdadeiras e falsas. 
que o direito à presunção de inocência como regra probatória remeta às regras probatórias previstas pelo direito cujo cumprimento exigiria não implica que estas devam ser incorporadas ao próprio direito fundamental.

\subsubsection{A PRESUNÇÃO DE INOCÊNCIA COMO REGRA DE JULGAMENTO}

A presunção de inocência, em sua faceta de regra de julgamento, aplica-se ao momento da valoração da prova, de modo que se a prova presente nos autos não resulta conclusiva para demonstrar a culpabilidade do acusado, a dúvida se resolva a favor da inocência dele. Esta, por outra parte, é a tradicional leitura da presunção de inocência na doutrina anglo-saxã.

Por razões que espero poder demonstrar no que se segue, considero que esta faceta da presunção de inocência, como regra de julgamento, é crucial se a presunção de inocência deve julgar um papel de garantia processual do cidadão. Contudo, surpreendentemente, essa faceta foi a mais descuidada e recebeu um tratamento doutrinário e jurisprudencial muitas vezes lamentável.

Convém sinalizar, em primeiro lugar, o difícil caminho adotado pelo Tribunal Constitucional espanhol (e seguido pela maioria de nossa doutrina) no que se refere à relação entre presunção de inocência e o princípio in dubio pro reo ${ }^{41}$. Inicialmente, o Tribunal considerou o reconhecimento do direito à presunção de inocência do artigo $24.2 \mathrm{da}$ Constituição espanhola como a constitucionalização daquele princípio ${ }^{42}$. Por outro lado, por motivos estritamente pragmáticos encaminhados a restringir o acesso através do recurso de amparo à jurisdição constitucional em reclamação da violação da presunção de inocência, em sua faceta de

41 Veja-se uma excelente apresentação da evolução jurisprudencial e doutrinária espanhola em: FERNÁNDEZ LÓPEZ, op. cit., p. 162 e ss.

42 Neste sentido, vid a STC 31/1981, F.J. $2^{\circ}$, seguida depois por muitas outras. Resulta especialmente clara a STC 107/1983, F.J. 20, ao afirmar que "a presunção de inocência, que limitadamente vinha sendo mero princípio teórico do direito, no âmbito da jurisdição criminal, através do axioma in dubio pro reo, relacionado com a valoração benigna das provas em casos de incerteza, passou a ser um amplo direito fundamental quando constitucionalizou a sua existência no artigo 24.2, C.E (...)" (tradução livre). 
regra de julgamento, posteriormente modificou-se essa doutrina ${ }^{43}$ para passar a sustentar-se uma radical diferença entre presunção de inocência e in dubio pro reo.

Assim, sustenta-se que a presunção de inocência é aplicável unicamente às hipóteses nas que não há prova de autoria (ou quando as provas não tenham sido praticadas respeitando as garantias processuais), enquanto que o princípio in dubio pro reo é uma regra de valoração da prova dirigida ao juiz ou tribunal determinando a absolvição do imputado se, praticadas as provas da acusação, a ele sobraram dúvidas acerca da ocorrência dos fatos delituosos ou da participação do acusado neles. A consequência prática dessa distinção é que a presunção de inocência não abarcaria a faceta de regra de julgamento: dizer que não se pode condenar sem prova de autoria não é, em precisão teórica ou tampouco prática, uma regra de julgamento sobre a valoração da prova, visto que seria aplicável apenas na ausência de prova. Mas se a faceta de regra de julgamento da presunção de inocência é crucial se concebida como uma garantia processual, então tal interpretação resultaria numa total desproteção constitucional de dita garantia ${ }^{44}$.

Sem embargo, para maior confusão, o próprio Tribunal Constitucional sustentou também repetidas vezes o status de regra de julgamento à presunção de inocência, cuja função suporia a constitucionalização do standard de prova penal. Assim, a presunção de inocência imporia a obrigação de absolver se o resultado da valoração da prova não alcança o standard de prova indicado. Mas, qual é esse standard de prova? Nos primeiros anos da jurisprudência constitucional e também na tradicional jurisprudência do Tribunal Supremo, essa pergunta era respondida

43 Fundamentalmente a partir de 1989, ainda que se possa encontrar precedentes desde dois ou três anos antes. A primeira teorização da diferença entre presunção de inocência como regra de julgamento e o in dubio pro reo pode ser encontrada na STC 44/1989, F.J, 2o. Em um sentido muito crítico à distinção elaborada, vid.: ANDRÉS IBÁÑ̃Z, Perfecto: Presunción de inocencia y prisión sin condena, en Detención y prisión provisional. Cuadernos de Derecho Judicial, CGPJ, Madrid, 1996; citado por la reimpresión en Id.: En torno a la jurisdicción, Buenos Aires: Editores del Puerto, 2007, p. 257, nota 25; FERNÁNDEZ LÓPEZ, op. cit. p. 178 e ss.

44 CAAMAÑO, F. La garantía constitucional de la inocencia, Valencia: Tirant lo Blanch, 2003, p. 246. 
apelando à íntima convicção ou à apreciação em consciência, sinalizada como critério de valoração da prova no artigo 741.1 de la Ley de Enjuiciamiento Criminal. Assim, nessa versão claramente subjetivista, a STC 124/1983 afirma que:

\begin{abstract}
"Por outra parte, convém também sinalizar aqui que o raciocínio do Juiz da Instrução de Noya, contido no considerando primeiro de sua sentença é impecável desde o ponto de vista constitucional, isto é, sob o enfoque do art. 24.2 da C.E., pois se a ele, sob o sistema da livre apreciação da prova do art. 741 da Ley de Enjuiciamiento Criminal, as provas praticadas não lhe convenceram da culpabilidade dos acusados, atuou perfeitamente os absolvendo, porque sob o imperativo do art. 24.2 da C.E. é evidente que ninguém pode ser condenado apenas porque 'existam indícios que apontam à possível participação' do ou dos acusados nos atos delituosos. Sucede, sem embargo, que se com os mesmos elementos probatórios outro Tribunal, o de apelação, 'apreciando segundo a sua consciência as provas praticadas em juízo' (art. 741 da Ley de Enjuiciamiento Criminal) chega a um resultado contrário, e neste caso, ao convencimento razoável e racional da culpabilidade dos antes absolvidos, não por isso pode-se afirmar violação alguma contra a presunção de inocência, sempre que as provas praticadas em juízo sejam as que proporcionem fundamento para a sua convicção. Desse modo, não se pode falar de vulneração da presunção de inocência, senão de uma discrepância na valoração da prova realizada pelos órgãos judiciais igualmente livres para valorar em consciência, com o resultado de que entre ambas as valorações há de se impor a do Tribunal de apelação" (tradução livre).
\end{abstract}

Isto é, os órgãos judiciais, o Juiz de Noya e o Tribunal de apelação valoram em consciência a prova, de modo subjetivo, e o Tribunal de apelação manda mais ${ }^{45}$. O difícil é entender aqui qual é a regra de julgamento que se impõe aos julgadores e qual a garantia que se outorga ao cidadão imerso em um processo penal. Mais recentemente, no entanto, tanto o Tribunal Supremo como o Constitucional sustentaram que a presunção

45 A semelhantes consequências chegam todos os autores que sustentam uma concepção subjetivista, irracionalista da valoração da prova. Valha como exemplo: VEGAS TORRES, op. cit., p. 181. 
de inocência como regra de juízo supõe que somente pode se condenar se o resultado das provas suporta a tese da culpabilidade do acusado além de toda dúvida razoável, incorporando assim o típico standard de prova penal anglo-saxão. Um exemplo por todos:

"O direito à presunção de inocência comporta o direito a não ser condenado sem provas de autoria válidas, o que implica que toda sentença condenatória penal; ademais, ditas provas hão de haver sido obtidas com as garantias constitucionais, haver-se praticado normalmente no juízo oral e haver-se valorado e motivado pelos Tribunais respeitadas as regras da lógica e da experiência, de tal modo que se possa afirmar que a declaração de culpabilidade ficou estabelecida além de toda dúvida razoável 46" (Grifei)

Claro que a perplexidade sobre isso aumenta mais se se atende ao que diz a STC 209/2007:

"Na análise da razoabilidade dessa regra que relaciona os indícios ao fato provado, temos de precisar agora que somente podemos considerá-la insuficiente desde as exigências do direito à presunção de inocência se, à vista da motivação judicial da valoração do conjunto da prova, cabe apreciar um modo indubitável desde uma perspectiva objetiva e externa que a versão judicial dos fatos era mais improvável que provável. Em tais casos, não caberá estimar como razoável nem que o órgão judicial atuou com uma convicção suficiente (além de toda dúvida razoável), nem a convicção em si” ${ }^{47}$. (Grifei)

Como se pode apreciar, o nível da confusão acerca da relação entre presunção de inocência e standard de prova penal é muito considerável. Urge, pois, esclarecer o sentido e o alcance da presunção de inocência como regra de julgamento do processo penal.

46 STC 43/2003, F.J. $4^{\circ}$ (tradução livre). No mesmo sentido, de forma muito clara, expressa a STC 66/2009, F.J. $6^{\circ}$. Para citar sentenças do Tribunal Supremo, ver as SSTS 258/2003, de 25 de fevereiro, F.J. $3^{\circ}$ e 1991/2002, de 25 de novembro, F.J. $13^{\circ}$.

47 SSTC 145/2005, de 6 de junho, 70/2007, de 16 de abril (tradução livre). 
Primeiramente, deve-se dizer que, contra o que sustenta a jurisprudência e a maior parte da doutrina, o direito à presunção de inocência pressupõe a vigência de um standard de prova, mas não implica qualquer standard específico. Com efeito, como sinalizei no início desse item, esse direito, em sua faceta de regra de julgamento, supõe que o acusado deve ser absolvido em caso de dúvida sobre a sua culpabilidade. Mas, de quê dúvida estamos falando? Creio que cabem três possibilidades:

a) Do estado psicológico de dúvida que as provas praticadas no processo podem suscitar no julgador. Esta é a resposta típica das concepções subjetivistas da prova, que não apenas são incompatíveis com a valoração racional da prova, senão que também com uma concepção garantista da presunção de inocência.

b) Da dúvida como incerteza racional. Este é o outro lado da certeza racional sobre os fatos do mundo. Contudo, dado que a certeza racional não pode ser alcançada nunca sobre fato algum $^{48}$, a dúvida teria sempre seu espaço e, entendida neste sentido, levaria sempre à absolvição e à inutilidade motivadora do direito penal.

c) De um certo grau de dúvida racional sobre a verdade de uma hipótese fática, complementar ao grau de corroboração dela mesma.

Dado que, por distintas razões, as possibilidades a) e b) devem ser rechaçadas, apenas fica de pé a possibilidade interpretativa c). No entanto, ela deixa aberta a questão de quê grau de dúvida sobre a hipótese da acusação de um processo penal é compatível com a condenação do acusado. Portanto, a presunção de inocência como regra de julgamento, expressão do in dubio pro reo, a) nada nos diz sobre o grau de dúvida racional admissível, isto é, sobre o standard de prova que deverá ser utilizado no processo penal ${ }^{49}$, mas b) sim pressupõe que se disponha de um

48 Como diria Tomás de Aquino, "in negotiis humanis non potest haberi probatio demonstrativa et infallibilis, sed sufficit aliqua coniecturalis probabilitas". Vid. Tomás de Aquino, Summa Theologiae, Ia, IIae, quaestio CV, art. 2, ad octavum.

${ }^{49}$ Desse modo, poder-se-ia dizer que a presunção de inocência é compatível com distintos standards de prova, não necessariamente muito elevados. As razões para fixar o standard de prova em um ponto de alta exigência probatória têm a ver mais com a distribuição de la ratio de erros positivos (inocentes condenados) e negativos (culpados absolvidos) que, como sociedade, estamos dispostos a suportar. Ao respeito, vid.: STEIN, A. Foundations of Evidence Law, Oxford: Oxford University Press, 2005, p. 133-4; LAUDAN, L. 
standard de prova cuja aplicação seja intersubjetivamente controlável, para tornar viável a função de garantia da presunção de inocência. É por isso que a situação atual na Espanha e nos países de nosso entorno inviabiliza a aplicabilidade da presunção de inocência como regra de julgamento, isto é, como garantia do cidadão frente à valoração da prova. Se não se dispõe de um standard de prova intersubjetivamente controlável, a presunção de inocência como regra de julgamento não pode ser operativa, visto que não se sabe frente a que resultado probatório o cidadão terá direito a uma declaração de inocência.

Em um trabalho anterior ${ }^{50}$, propus um exemplo de standard de prova para a hipótese acusatória em um processo penal. Não tinha então a pretensão de ser uma proposta de lege ferenda no que se refere ao seu conteúdo, mas sim a respeito do modo de formular um standard desse tipo para que fosse intersubjetivamente controlável. Reitero-o agora com a mesma pretensão:

Imaginemos que nossa lei de processo criminal estabelecesse que para considerar provada a hipótese da culpabilidade devam se dar conjuntamente as seguintes condições: 1) A hipótese deve ser capaz de explicar os dados disponíveis, integrando-os de forma coerente, e as predições de novos dados que a hipótese permita formular devem restar confirmadas; 2) É preciso que todas as demais hipóteses plausíveis explicativas dos mesmos dados e que sejam compatíveis com a inocência do acusado tenham sido refutadas, excluídas as hipóteses meramente ad hoc.

Com uma formulação desse tipo, ficariam claras as condições para que se proceda à condenação do acusado e, complementarmente, as condições nas que ele teria direito à absolvição. A motivação da sentença em matéria de fatos deveria então justificar que a resolução adotada cumpre com os requisitos estabelecidos pelo standard. No entanto, poder-se-ia pensar que uma vez estabelecido o standard, cuja determinação está exigida pela presunção de inocência, mas não se deriva dela no que tange ao grau de exigência probatória, a presunção de inocência como

Truth, Error, and Criminal Law. An Essay in Legal Epistemology, Cambridge: Cambridge University Press, 2006, p. 68; FERRER BELTRÁN, J. La valoración racional de la prueba, Madrid: Marcial Pons, 2007, p. 139 e ss.

FERRER, op. cit., p. 147. 
regra de julgamento já não tem outra função. Dito de outro modo, uma vez determinado o nível da dúvida racional compatível com a condenação do acusado, já não sobraria espaço para o in dubio pro reo. Contudo, esta não é exatamente a situação. Por preciso que seja um standard de prova que se adote, sempre ficará uma margem de vagueza sobre ele; i.e., sobre o exato grau de dúvida racional compatível com a condenação. Nestas hipóteses, faz-se necessária uma regra de segunda ordem, que estabeleça o que deve ser realizado no caso de dúvida sobre a satisfação do standard. E é aqui onde resultaria aplicável a presunção de inocência como in dubio pro reo: em caso de dúvida sobre a satisfação do standard, a absolvição do acusado seria devida.

\section{DE NOVO SOBRE A PRESUNÇÃO DE INOCÊNCIA COMO REGRA SOBRE O ONNUS DA PROVA}

A análise das implicações para o ônus da prova do reconhecimento do direito da presunção de inocência deve ser, em minha opinião, algo mais cuidadoso que o habitual com o conceito de ônus da prova. Com efeito, em minha opinião, convém incorporar a distinção tipicamente anglo-saxã entre o burden of proof e o burden of producing evidence. No primeiro sentido, a distribuição do ônus da prova supõe determinar qual das partes se verá prejudicada pela falta de prova, i.e., quem perde o processo se não se cumpre o standard de prova aplicável ao mesmo. No segundo sentido, o ônus da prova rege qual das partes deve produzir todas ou alguma prova no processo. É importante advertir que, de forma geral, os dois sentidos de ônus da prova não têm porquê favorecer a mesma parte. É perfeitamente possível que uma parte tenha sobre si o ônus no primeiro sentido, de maneira que a falta de prova faça com que seja ela quem perde o processo e, ao mesmo tempo, que faça recair sobre a parte contrária o ônus de produzir ou trazer provas (ou algumas provas) ao processo, dado que, por exemplo, é mais fácil para ela trazê-las, ou bem, simplesmente, reconhece-se que as provas estão em seu poder.

Pois bem, a presunção de inocência diz algo sobre os sentidos de ônus da prova? Em minha opinião, a resposta é não. Evidentemente, pode-se dizer, de forma geral, que em um processo penal o ônus da prova, entendido como regra que determina quem é prejudicado pela falta de 
prova, recai sobre a acusação. Mas isso não é consequência da presunção de inocência em si mesma, senão do standard de prova (que, recordemos, está pressuposto, mas não é implicado pela presunção de inocência).

Agora, justificar este ponto exige algum argumento adicional: como se pôde ver na epígrafe anterior, apresentei um standard de prova que opera unicamente a respeito da hipótese de culpabilidade. Isso é assim porque, em minha opinião, não existe razão para que os standards de prova aplicáveis à hipótese de culpabilidade e à hipótese de inocência sejam iguais. Com efeito, a razão que temos para aplicar um standard de prova muito exigente no processo penal parece ser que o bem em jogo, i.e., a liberdade do acusado, é muito valioso e, portanto, é preciso ter um alto grau de probabilidade de acertar para sacrificá-lo ${ }^{51}$. Mas essa razão não opera, obviamente, no caso da ou das hipóteses da defesa. Se aumentamos as exigências probatórias para diminuir as probabilidades de que um sujeito inocente seja condenado e, portanto, privado de sua liberdade, não tem sentido aplicar as mesmas exigências à hipótese da defesa. Por essa razão, no processo penal teremos standards de prova assimétricos para a acusação e para a defesa.

Sendo assim, a falta de satisfação de cada um dos standards de prova, da acusação e da defesa, prejudicará a parte que não haja conseguido alcançar o grau de corroboração de suas hipóteses exigido pelo seu respectivo standard aplicável. Se a hipótese da acusação não alcança o nível de corroboração requerido pelo standard de prova que lhe é aplicável, esta não poderá ser considerada provada e, portanto, a falta de prova prejudicará a acusação. Mas o mesmo não poderá ser dito da hipótese de inocência: se a defesa alegou, por exemplo, um álibi e não consegue produzir corroboração suficiente que lhe permita superar o standard de prova aplicável à hipótese da inocência, então essa falta de prova irá em prejuízo de suas pretensões. A diferença relevante entre as situações das duas partes, no que se refere à falta de prova suficiente, derivada

51 Está claro que, hoje em dia, nem todos os delitos têm como consequência jurídica a pena de privação de liberdade (ou, em alguns países, a ainda mais grave perda da vida). A expansão sem medida do direito penal supôs também a diversificação dos tipos de penas. Esta é, em minha opinião, uma boa razão para que também os standards de prova penais possam ser diversos, mais ou menos exigentes, em função dos bens em jogo no caso de que haja condenação. 
da assimetria dos respectivos standards de prova, é que se a defesa não consegue superar o standard de prova que lhe resulta aplicável, isso implica que não podemos considerar provada a inocência, mas não que a defesa não possa ganhar o caso mediante a absolvição do acusado. Por outro lado, se acusação não consegue produzir corroboração suficiente à sua hipótese, isso implicará na perda do caso para esta parte. Isso é consequência da formulação do standard de prova que lhe é aplicável e por isso pode-se dizer que o ônus da prova, no sentido de burden of proof anglo-saxão, está presente.

Em contrapartida, as coisas são diferentes se colocamos atenção ao ônus da prova no sentido de a quem corresponde a integração ou produção de provas (burden of producing evidence). Com efeito, a introdução da distinção entre os dois sentidos de ônus da prova nos permite ver, em minha opinião, que nada exclui na maioria dos sistemas jurídicos modernos, que a defesa deva integrar provas ao processo se assim se ordena, por exemplo, devido a que a ela resulta mais fácil integrá-la ou porque é ela quem dispõe da prova que se considera relevante. Para dar apenas um exemplo, é perfeitamente possível que se peça a um médico acusado de homicídio por negligência em uma intervenção cirúrgica que traga o expediente clínico do paciente ou outras provas médicas sobre os antecedentes da intervenção e da intervenção mesma. Evidentemente, a razão disso é que é ele quem dispõe dessas provas, que não são acessíveis à outra parte. E isso não se considera em nossos sistemas como atentatório à presunção de inocência. Em outras palavras: a presunção de inocência parece ser compatível, neste sentido, com a atribuição de ônus probatório (no sentido de ônus de integrar e produzir provas) à defesa em um processo penal.

\section{Conclusão}

No trajeto realizado até aqui, pretendi demonstrar:

1. Que a presunção de inocência na jurisprudência e na doutrina espanhola foi tratada como um direito multifacetado com tendência à hipertrofia.

2. Que boa parte das facetas que são atribuídas a esse direito (extraprocessual, com matizes, como princípio informador 
e como regra probatória) são supérfluas e, portanto, poderiam ser separadas da presunção de inocência, diminuindo a hipertrofia dessa última.

3. Que a presunção de inocência como regra de tratamento processual tem perfeito sentido, mas deve se resolver com maior claridade conceitual sua relação com as medidas cautelares no processo penal, em especial, com a prisão preventiva.

4. E, finalmente, que a presunção de inocência como regra de juízo não é operativa se não se dispõe de um standard de prova cuja aplicação seja intersubjetivamente controlável. Se se dispõe dele, o espaço para a aplicação da presunção é o da dúvida sobre a satisfação do standard.

\section{REFERÊNCIAS}

ALONSO OLEA, M.; CASAS BAAMONDE, M.E. Derecho del trabajo, Madrid: Civitas, 1987.

ANDRÉS IBÁÑEZ, Perfecto. Acerca de la motivación de los hechos en la sentencia penal. Doxa: Cuadernos de Filosofia del Derecho, n. 12, p. 257-299, 1992, https:// doi.org/10.14198/doxa1992.12.08

ANDRÉS IBÁÑEZ, Perfecto. Presunción de inocencia y prisión sin condena, en Detención y prisión provisional. Cuadernos de Derecho Judicial, CGPJ, Madrid, 1996; citado por la reimpresión en Id.: En torno a la jurisdicción, Buenos Aires: Editores del Puerto, 2007.

ARMENTA DEU, T. La prueba ilícita (un estudio comparado), Madrid: Marcial Pons, 2009.

BECCARIA, C. Dei delitti e delle pene, Milano: Mondadori, 1764, 1991.

CAAMAÑO, F. La garantía constitucional de la inocencia, Valencia: Tirant lo Blanch, 2003.

CHIAVARIO, M. Presunzione d'innocenza e diritto di difesa nel pensiero di Francesco Carrara, en AA.VV.: Francesco Carrara nel primo centenario della morte. Atti del convegno internazionale, Lucca-Pisa, 2-5 giugno 1988, Milano: Giuffre, 1991.

DE AQUINO, T. Summa Theologiae, La Editorial Católica, Madrid, 1956. 
DE LA OLIVA SANTOS, A. Sobre la ineficacia de las pruebas ilícitamente obtenidas, Tribunales de Justicia, $\mathrm{n}^{\circ}$ 8-9, 2003.

ESMEIN, A. Histoire de la procédure criminelle en France: et spécialement de la procédure inquisitoire depuis le XIIIe siècle, L. Larose et Forcel, Paris, 1882.

FERNÁNDES LÓPEZ, M. Prueba y presunción de inocencia, Madrid: Iustel, 2005.

FERRAJOLI, Luigi. Diritto e ragione. Teoria del garantismo penale, Roma-Bari: Laterza, 1998.

FERRER BELTRÁN, J. Prueba y verdad en el derecho, $2^{\mathrm{a}}$ ed., Madrid: Marcial Pons, 2003.

FERRER BELTRÁN, J. La valoración racional de la prueba, Madrid: Marcial Pons, 2007.

GIMENO SENDRA, J.V. Los derechos de acción penal, al juez legal y de defensa y sus derechos instrumentales, in Cobo del Rosal (dir.): Comentarios a la legislación penal, tomo I, Madrid: Edersa, 1982.

GÓMEZ COLOMER, J.L. (ed.). Prueba y proceso penal. Análisis especial de la prueba prohibida en el sistema español y en el derecho comparado, Valencia: Tirant lo Blanch, 2008.

HASSEMER, W. Die Voraussetzungen der Untersuchungshaft, Der Strafverteidiger, $\mathrm{n}^{\circ} 1$; citado por la traducción castellana de Ziffer, P.: Los presupuestos de la prisión preventiva, in Hassemer, W.: Crítica al derecho penal de hoy, Buenos Aires: Ad Hoc, 1984, 1995.

HOBBES, T. Leviatán, trad. a cargo de Mellizo, C., Madrid: Alianza Universidad, $1651,1989$.

HOHFELD, W.N. Some Fundamental Legal Conceptions as Applied to Judicial Reasoning", Yale Law Journal, 16, n 23. Citado por la traducción castellana de Carrió, G.: Conceptos jurídicos fundamentals, México, D.F.: Fontamara, 1913, 1992. https://doi.org/10.2307/785533

ILLUMINATI, G. La presunzione d'innocenza dell'imputato, Bologna: Zanichelli, 1979.

LAUDAN, L. Truth, Error, and Criminal Law. An Essay in Legal Epistemology, Cambridge: Cambridge University Press, 2006. https://doi.org/10.1017/ cbo9780511617515

LUZÓN CUESTA, J.Ma . La presunción de inocencia ante la casación, Madrid: Colex, 1991. 
MENDONCA, D. Presunciones, Doxa, nº 21, vol. 1, 1998.

MIRANDA ESTRAMPES, M. La mínima actividad probatoria en el proceso penal, Bosch, Barcelona, 1997.

MIRANDA ESTRAMPES, M. La regla de exclusión de la prueba ilícita: historia de su nacimiento y de su progresiva limitación, Jueces para la Democracia, 47, 2003.

MONTAÑ́́S PARDO, M.A. La presunción de inocencia. Análisis doctrinal y jurisprudencial, Pamplona: Aranzadi, 1999.

MONTESQUIEU. De l'esprit des lois, Garnier Frères Libraires-Éditeurs, Paris, $1748,1878$.

OVEJERO PUENTE, A. Ma . Constitución y derecho a la presunción de inocencia, Valencia: Tirant lo Blanch, 2006.

PASTOR, Daniel. Las garantías de libertad del imputado, en AA.VV.: Garantismo y crisis de la justicia, Universidad de Medellín, Medellín, 2010.

PEDRAJAS MORENO, A. Despido y derechos fundamentales. Estudio especial de la presunción de inocencia, Madrid: Trotta, 1992.

RAMOS MÉNDEZ, F. El proceso penal. Lectura constitucional, Barcelona: Ed. Bosch, 1988.

RODRIGUEZ-PIÑERO, M. Carga de la prueba y presunción de inocencia en el proceso de despido, Relaciones laborales: revista crítica de teoría y práctica, $\mathrm{n}^{\circ}$ 8, 1990.

ROMERO ARIAS, E. La presunción de inocencia, Aranzadi, Pamplona, 1985.

STEIN, A. Foundations of Evidence Law, Oxford: Oxford University Press, 2005. https://doi.org/10.1093/acprof:oso/9780198257363.001.0001

TOMÁS Y VALIENTE, F. “In dubio pro reo, libre apreciación de la prueba y presunción de inocencia”, en Revista Española de Derecho Constitucional, n 20, 1987.

VÁZQUEZ SOTELO, J.L. Presunción de inocencia del imputado e íntima convicción del tribunal (Estudio sobre la utilización del imputado como fuente de prueba en el proceso penal español), Barcelona: Ed. Bosch, 1984.

VEGAS TORRES, J. Presunción de inocencia y prueba en el proceso penal, Madrid: La Ley, 1993.

VOLTAIRE, Commentaire sur le livre Des délits et des paines, par un advocat de province, Paris, 1766.

WRÓBLEWSKI, J. Structure et fonctions des présomptions juridiques, en Perelman, Ch. y Foriers, P.: Les présomptions et les fictions en Droit, Bruxelles: Bruylant, 1974. 


\section{Informações adicionais e declarações dos autores (integridade científica)}

Agradecimentos: Este trabalho foi fruto de uma elaboração em diversas etapas. Em todas elas tive a sorte de contar com amigos que leram criticamente seus diversos rascunhos. Quero agradecer especialmente as atinadas e generosas observações de Perfecto Andrés Ibáñez, Daniel González Lagier, Larry Laudan, Diego Papayannis, Daniel Pastor, Janaina Roland Matida, Michele Taruffo, Jonathan Valenzuela e Carmen Vázquez. Também tive a oportunidade de expor o trabalho em diversos encontros, como o II Miniforo de Epistemologia Jurídica (México, DF), o XVI Congresso Ítalo-espanhol de teoria do direito (Barcelona), o III Congresso Internacional de Direito Processual: Garantismo e Crise da Justiça (Cartagena das Índias) e as II Jornadas Bi-nacionais de Direito processual (Lima). Agradeço a todos os seus participantes pelas sugestões realizadas em seus respectivos debates e à Janaina Roland Matida pela excelente tradução ao português.

Declaração de conflito de interesses (conflict of interest declaration): o autor confirma que não há conflitos de interesse na realização das pesquisas expostas e na redação deste artigo.

Declaração de coautoria e especificação das contribuições (declaration of authorship): todas e somente as pessoas que atendem os requisitos de autoria deste artigo estão listadas como autores; o autor se responsabiliza integralmente por este trabalho em sua totalidade.

- Tradução do espanhol ao português: Janaina Matida (orcid. org/0000-0003-0963-1848)

Declaração de ineditismo e originalidade (declaration of originality): este artigo é uma versão traduzida e revisada do trabalho originalmente publicado em espanhol em: FERRER BELTRÁN, Jordi. Una concepción minimalista y garantista de la presunción de inocencia. In: MARTÍ MARMOL, Josep Lluís; MORESO, Josep Joan (orgs), Contribuciones a la filosofía del derecho, Madrid: Marcial Pons, 2012; o autor assegura que não há plágio de terceiros. 
Dados do processo editorial

(http://www.ibraspp.com.br/revista/index.php/RBDPP/about/editorialPolicies)

- Recebido em: 17/12/2017

Equipe editorial envolvida

- Retorno rodada de correções: 28/01/2018

- Editor-chefe: 1 (VGV)

- Autor convidado

- Editor-associado: 1 (GHB)

http://www.ibraspp.com.br/revista/index.php/

RBDPP/about/editorialPolicies - custom-1

\section{COMO CITAR ESTE ARTIGO:}

FERRER BELTRÁN, Jordi. Uma concepção minimalista e garantista de presunção de inocência. Revista Brasileira de Direito Processual Penal, Porto Alegre, vol. 4, n. 1, p. 149-182, jan./abr. 2018. https://doi.org/10.22197/rbdpp.v4i1.131

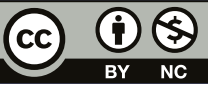

Esta obra está licenciada com uma Licença Creative Commons Atribuição-NãoComercial 4.0 Internacional. 